\title{
River and Wetland Restoration: Lessons from Japan
}

\author{
KEIGO NAKAMURA, KLEMENT TOCKNER, AND KUNIHIKO AMANO
}

\begin{abstract}
River and wetland restoration has emerged as a worldwide phenomenon and is becoming a highly profitable business. Although researchers worldwide know a lot about restoration practices in Europe and the United States, we have only scant information about the activities in Japan, where more than 23,000 river restoration projects have been conducted during the past 15 years. In Japan, restoration is a daunting business because of the high human population density, urbanization, and harsh environmental conditions. Here we provide an overview of the various restoration activities in Japan and discuss the lessons that we can draw from them.
\end{abstract}

Keywords: conservation, rehabilitation, biodiversity, floodplain, lake

A s the 21st century begins, the issue of sustainable ecosystem management is providing humanity with one of its greatest challenges. The problem is particularly complex for freshwater systems, where humans and natural systems are inherently linked. Increasing water demands for an expanding human population competes with protecting aquatic ecosystems and ecological services (MEA 2005). Today, rivers and wetlands are among the most threatened ecosystems worldwide (Brinson and Malvarez 2002, Malmqvist and Rundle 2002, Tockner and Stanford 2002). As a consequence, restoration of rivers and wetlands has emerged as a worldwide phenomenon as well as a booming enterprise (Kondolf 1995, Brookes and Shields 1996, Nienhuis and Leuven 2001, Shields et al. 2003, Bernhardt et al. 2005, Palmer et al. 2005). In the United States, for example, public and private organizations have spent about $\$ 15$ billion on more than 30,000 river and wetland restoration projects since 1990 (Malakoff 2004, Bernhardt et al. 2005). With the rapid increase in restoration projects, scientific knowledge is also increasing. However, scientists are mainly informed about progress made in the United States and Europe. Although the total number of restoration projects in Japan is almost as high as in the United States, the ratio of relevant scientific publications in international journals is about 1:100 (based on a search of ISI Web of Science for publications between January 1985 and February 2006).

In Japan, river restoration has been growing rapidly since the early 1990s (figure 1). Most projects have been carried out under harsh environmental conditions in urban and suburban areas. Therefore, experience gained in Japan can be applied to countries that share similar conditions, such as the Asian monsoon region and the European Alps. In this article, we present a brief characterization of the country's environmental settings, provide a historic overview of river and wetland management in Japan, introduce recent agendas for restoration, and present three key case studies in more detail. Finally, we discuss some general lessons that can be drawn from the various restoration activities in Japan.

\section{A unique environmental setting}

Embedded within the circum-Pacific volcanic belt called the "Ring of Fire," the Japanese Archipelago (land area: 377,880 square kilometers $\left[\mathrm{km}^{2}\right]$ ) extends north-south over a distance of approximately $2000 \mathrm{~km}$ and east-west over a maximum distance of $300 \mathrm{~km}$ (Iyama 1993). Geologically, Japan is young, tectonically active, rugged, and mountainous ( $>70 \%$ mountains), with a wet climate (average annual rainfall: 1714 millimeters) and dense forest cover (> 60\%; Kornhauser 1982).

Japanese rivers are unique. They are steep, short (the longest is the Shinano River at $367 \mathrm{~km}$ ), flashy (i.e., prone to rapid rises and drops in water level after rainfall), and sediment rich (Yoshimura et al. 2005). The river regime coefficient

\footnotetext{
Keigo Nakamura is a senior researcher in, and Kunihiko Amano is head of, the River Restoration Team at the Public Works Research Institute, 1-6 Minamihara, Tsukuba, 305-8516, Japan. Klement Tockner (e-mail: klement. tockner@eawag.ch) is head of the research group on floodplain ecology at the Department of Aquatic Ecology of the Swiss Federal Institute of Aquatic Science and Technology and associate professor for aquatic ecology at the Institute of Integrative Biology of the Swiss Federal Institute of Technology in Zurich, Switzerland; this manuscript was written while he was a visiting scientist at the Institute of Ecosystem Studies, Millbrook, NY 12545. (C) 2006 American Institute of Biological Sciences.
} 


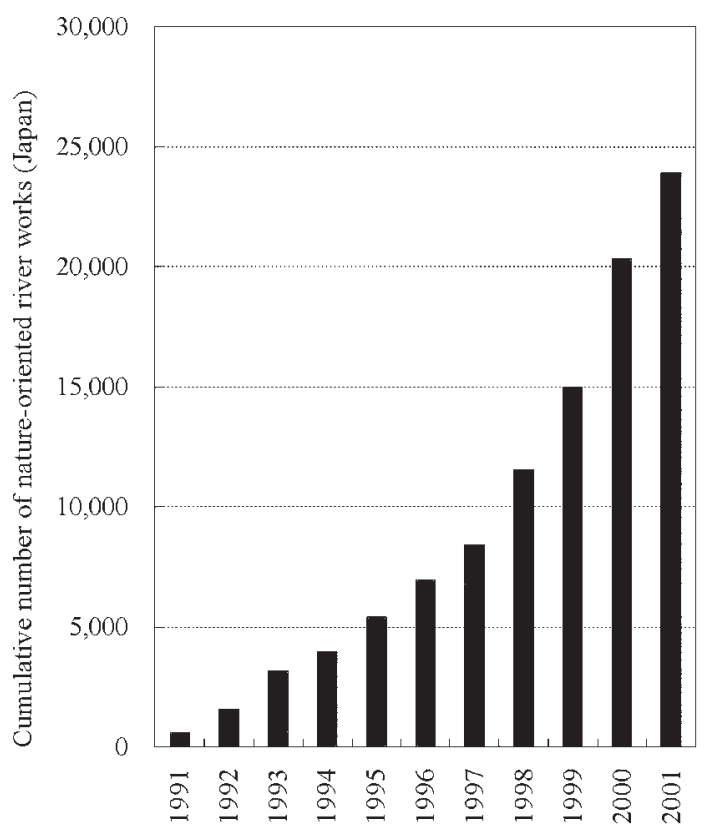

Figure 1. The cumulative number of restoration projects undertaken in Japan as part of the "Nature-oriented River Works" initiative (1991-2001).

(the ratio of maximum to minimum stream flow) ranges from 200 to 400, up to an order of magnitude higher than for continental rivers (Oguchi et al. 2001).

The human population of Japan, with an average density of 340 people per $\mathrm{km}^{2}$ (SBJ 2001), is concentrated in urban and suburban areas along the coast and on alluvial plains. Seventy-three percent of the population lives in 10 large urban agglomerations (e.g., Tokyo-Yokohama, with a population of 20 million). Floodplains are of particular strategic importance. They cover less than $10 \%$ of the land but contain $51 \%$ of the population and $75 \%$ of the assets (MOC 1995, Yoshikawa 2004). On the Kanto and Osaka plains, for example, average population density exceeds 5000 people per $\mathrm{km}^{2}$ (SBJ 2001). Hence, for centuries, river regulation and flood control have been critical for protecting human life and supporting economic growth.

Japan has a rich freshwater fauna and flora, including many endemic species. A distinct latitudinal gradient (subarctic to subtropic climate), in combination with the radial character of the river network, results in a high spatial differentiation of freshwater biota (Taniguchi et al. 2001, Yoshimura et al. 2005).

\section{A brief history of river management in Japan}

Japan has a long tradition of using the natural resources of its rivers and wetlands. Rice has been the staple food for the country's population for more than 2000 years. Rice farming has created a diverse cultural landscape with extensive paddy fields, and complex stream channel networks and irrigation canals intermixed with natural wetlands (Sato 2001). Today, many common fish species (e.g., carp, crucian carp, catfish, and loach) are dependent on traditional paddy fields and irrigation systems for completing their life cycles.

Around the beginning of the Edo period (1603-1867), major progress in civil engineering and the development of new irrigation and embankment techniques enabled the conversion of large floodplains into paddy fields (Kornhauser 1982). An epoch-making project was the diversion of the lower Tone River from Tokyo Bay to the Pacific Ocean (Uzuka and Tomita 1993, Gippel and Fukutome 1998). With the realization of the eastward diversion of the Tone River, Tokyo started its rapid development from a swampy village to the world's largest city.

The Meiji Restoration (1868) marked the end of the samurai era. Foreign experts were invited to facilitate the modernization of the country. Dutch engineers, such as Johannis de Rijke and Cornelis Johannes van Doorn, played key roles in engineering rivers. Today, Dutch words such as peil, meaning water level, and krib (pronounced "kereppu" in Japan), meaning groin (a rigid structure built to protect the shore from erosion), are common technical terms in Japanese. However, adapting rivers for navigation failed, mainly because of the concurrent rapid railway extension. In 1896, after a series of damaging floods, the first River Law was enacted and flood protection became a key issue for the central government (Gippel and Fukutome 1998, Takeuchi 2002).

At the beginning of the 20th century, Bunkichi Okazaki (1872-1945) was a pioneer in early river conservation. He was responsible for flood control and navigation measurements along the Ishikari River (Hokkaido). Influenced by the Rhône River project in France, he "worked with the river" by preserving its natural geomorphic style (Asada 1994). He called this concept "naturalism." Unfortunately, his idea was poorly accepted in Japan at that time.

Between 1945 and 1960, disastrous typhoons and heavy floods killed about 20,000 people (FRICS 2002). For example, the Makurazaki Typhoon caused more than 2000 deaths in the Hiroshima Prefecture in 1945. The Catherine Typhoon in 1947 broke levees along the Tone River, flooded downtown Tokyo, and caused about 2000 deaths. In 1959, after the disastrous Isewan Typhoon killed approximately 5000 people in the Tokai region, the government commenced long-term flood control projects. In addition, the economic boom between 1950 and 1970 caused severe water pollution throughout the country. "Develop now, clean up later" was the maxim during this period. Rapid urbanization enlarged the area of impermeable landscapes, and further increased flooding risks. Within a few decades, most rivers had been constrained, impounded, and polluted (Yoshimura et al. 2005).

In the early 1970s, an energy crisis stopped rapid economic growth, and once again people started to recognize the value of natural landscapes and good living conditions. In urban and suburban areas, rivers provided the last remaining open space for amenities and recreation. Shin-sui"playing with water"-became an important buzzword. Countless shin-sui parks and playgrounds were opened along 
rivers. Although these projects were conducted for recreational rather than for ecological purposes, they helped to turn people's eyes back to nature. People started to acknowledge the importance of nature conservation and restoration. In 1981, the River Bureau of the Ministry of Construction (now the Ministry of Land, Infrastructure, and Transport, or MLIT), the main governmental authority for river management, mentioned for the first time in its annual report the equal importance of environmental, flood control, and water resource management issues. Pioneer river conservation projects in the early 1970s and 1980s were the embankment along the Ichinosaka River in 1974, built to provide highquality habitat for fireflies throughout their life cycle, and the rehabilitation of the urban Itachi River, Yokohama, in 1982 (Shimatani 2000).

The year 1990 was a turning point in river management. The River Bureau launched the initiative "Ta Shizen Gata Kawa Zukuri," or "Nature-oriented River Works," with the goal of conserving and restoring river corridors and their rich biodiversity. This initiative was strongly influenced by "Naturnaher Wasserbau" ("near-natural river engineering") in Switzerland and in Bavaria, Germany (Yamawaki 2000). Between 1990 and 2004, more than 23,000 Nature-oriented River Works projects were initiated throughout Japan (figure 1). This trend was enforced by the amendment of the River Law in 1997, when "conservation and improvement of the river environment" was inserted as the principal goal in article 1. This amendment also asked for strong public and stakeholder involvement (bottom-up decisionmaking processes). Since then, several laws were enacted or amended in Japan that promote nature restoration: the Specified Nonprofit Activity Promotion Law, or NPO Law, enacted in 1998 to support NGO (nongovernmental organization) activities for nature restoration; the Seacoast Law, amended in 1999 for the protection of the seacoast environment; the Environment Impact Assessment Law (1999), which is of primary importance for conserving and protecting nature; and the Land Improvement Law, originally created to promote agricultural modernization but amended in 2001 to conserve the rural environment. In particular, the Nature Restoration Promotion Law (2003), which calls for a sound scientific underpinning for restoration projects, has stimulated countless restoration projects throughout the country.

\section{Today's agenda for managing river environments}

The River Law, amended in 1997, forms the basis for present river management. In order of their importance, rivers are classified as class A, class B, secondary, and regular rivers. All 109 class A rivers are managed by the central government (MLIT). The MLIT has 10 regional offices, and each controls about a dozen local "river offices." All other rivers are within the domain of prefectural and municipal authorities. For fiscal year (FY) 2004, the MLIT's annual budget for rivers was 1740 billion yen (approximately US $\$ 16.6$ billion), of which 131 billion yen (approximately US $\$ 1.2$ billion) are spent for conservation and rehabilitation (River Bureau 2004).
Flood control and environmental issues. Flood control is of primary importance for Japan's security. Between 1994 and 2003, average annual flood damage cost 567 billion yen (approximately US $\$ 5.4$ billion), the highest value for any country worldwide (MLIT 2005). On average, about 100 people per year have been killed by floods (FRICS 2002). The level of flood protection in Japan is lower than in most OECD countries. Only $66 \%$ of class A rivers are adequately protected against a 30- to 40-year flood event (Takeuchi 2002). As a consequence, in 2000 the River Commission of the Ministry of Construction recommended a river basin flood program. However, instead of building higher continuous levees, the commission recommended constructing ring dikes and floodproof buildings. Zoning and hazard maps were developed. In 2004, 10 unprecedented typhoons hit Japan. Floods, storms, debris flows, and landslides killed 215 people and caused serious economic damage. The typhoons demonstrated how vulnerable Japan still is to natural disasters. Moreover, climate change will most likely increase future risks of natural disasters (Takeuchi 2002). Thus, people in Japan demand better flood control but ask for an improvement of the river environment at the same time. The primary challenge for river managers is to harmonize these different requirements, which are often seen as contradictory.

Conservation of aquatic ecosystems. Human impacts such as river engineering, agricultural development, invasion by nonnative species, and urban development have degraded aquatic ecosystems throughout Japan (Yoshimura et al. 2005). Since 1868 , wetland area has decreased by approximately $60 \%$ (GSI 2001). Recently, the appearance of once common species such as medaka (Oryzias latipes, or Japanese rice fish) in the Red Data Book of Japan has shocked the public (MOE 2003). Today the conservation of aquatic ecosystems is of great importance in Japan, and many countermeasures have been implemented to slow or reverse the degradation of river habitat (MLIT 2001, ESJ 2002). In 2004, for example, the Invasive Alien Species Act was implemented to eradicate certain invasive species and to regulate their import, dispersal, and spread.

Worldwide, Japan has the fourth highest dam density (Gleick et al. 2002). There have been 2757 dams built higher than 15 meters (m), and 268 are under construction (as of April 2004; JDF 2005). Consequently, only 3 out of 109 class A rivers are free-flowing today (Yoshimura et al. 2005). In 1991, the MLIT started the program "River Works for Fish Migration" to restore longitudinal continuity. As of 2001, $670 \mathrm{~km}$ of rivers have been restored for fish migration, mainly by constructing fish pathways (Ikeuchi and Kanao 2003).

The hydrologic disconnection of traditional paddy fields from irrigation channels has increased aquatic habitat fragmentation. Agricultural modernization has transformed wet paddy fields into dry paddy fields during the winter season, resulting in the loss of key habitat for many aquatic animals (Sato 2001). The restoration of wet paddy fields is now an active management goal. For example, wet paddy fields 
around Lake Kabukurinuma have been restored for winter geese, and in October 2005 this area was designated as the first Ramsar site dominated by rice paddies (Matsugane 2006). Channels and paddy fields have been reconnected, either by creating simple fish pathways (Hata 2002) or by manipulating water levels. Although the number and total area of these activities are still small, a recently published handbook entitled The Guideline of a Cooperative Project for Fish Habitat in Local Streams (MLIT and MAFF 2004) is stimulating the creation of programs to reconnect channels and paddy fields. This epoch-making cooperative project is one of the first nationwide joint projects between agricultural and river authorities.

Most downstream river sections in Japan are leveed, and most riparian forests have been converted into paddy fields. In addition, many riparian forests have been cut to increase the flood-routing capacity of the channel. Recently, riparian forests have been reviewed from an ecological and aesthetic point of view. As a consequence, new guidelines to protect and afforest riparian forests have been developed and integrated in the River Law (MOC 1997a, Ito et al. 2001).

Loss of dynamics. The dynamic nature of alluvial floodplain rivers is a function of intact flow and sediment regimes interacting with the physiographic features and vegetation cover of the landscape. The widespread attenuation of sediment transport and annual floods has led to the encroachment of riparian vegetation onto the former gravel beds along many rivers. "White" rivers with bare gravel and sand bars have turned into "green" rivers dominated by vegetated terraces. Today, exposed gravel and sand bars are becoming rare habitat types. Gravel and sand excavation has been prohibited for most rivers since the 1960s. New dams are often equipped with a sediment flushing gate, and several older dams are now mounted with new sediment bypass facilities. For check dams, slit dams that trap only large rocks are used today, assuring an abundant sediment supply.

Flow augmentation is conducted mainly downstream of large dams (Osugi et al. 2004). To date, a minimum flow of $0.1-0.3 \mathrm{~m}^{3}$ per second for each $100-\mathrm{km}^{2}$ catchment, as recommended by the MLIT, has been established for about 3100 $\mathrm{km}$ of class A rivers (Okayama 2001). More recently, flow variability has been increased by so-called flexible dam operations (Okayama 2001, Osugi et al. 2004). The flood retention capacity of reservoirs is being used to create artificial floods. In FY 2001, 20 dams were used for such operations, which significantly improved habitat, water quality, and odor conditions downstream (Harada and Yasuda 2004, Osugi et al. 2004).

\section{The boom in river restoration activities}

In 1990, the MLIT launched the National Census of the River Environment to gather nationwide baseline information on the ecological state of river corridors. Following standardized protocols (MOC 1997b), data on fish, benthic invertebrates, plants, birds, and other biota are collected from 109 class A and 133 class B rivers at 5-year intervals (Okayama 2001,
Ikeuchi and Kanao 2003). All data are checked through a rigorous peer-review process and made publicly available. This intensive monitoring not only provides important information on long-term trends in biodiversity but also improves our scientific understanding of river ecosystems and supports the planning of river restoration projects.

In 1998, the Public Works Research Institute (a branch of the MLIT until its privatization in 2001) opened the Aquatic Restoration Research Center (ARRC) in Gifu Prefecture. The ARRC is one of the largest facilities worldwide devoted to restoration ecology (Kayaba 2003). The facility is designed to experimentally study the ecological effects of flow manipulation along different types of river channel. It is equipped with three 800-m-long experimental channels of different geomorphic types. Discharge can be manipulated by an upstream gate. Numerous research institutes are using the ARRC facility, which includes a research station, for controlled field experiments. ARRC is also an important education and training center. Within the first 6 years, more than 20,000 people visited the center.

Booming restoration activities stimulated the formation of new academic societies. The River Ecology Research Group of Japan, founded in 1995, is an interdisciplinary association of ecologists, civil engineers, and river managers. Its members are engaged in five large river studies, involving the Tama River (Tokyo), the Chikuma River (Nagano), the Kizu River (Kyoto), the Kita River (Miyazaki), and the Shibetsu River (Hokkaido; Tsushima et al. 2002). Moreover, the Society of Ecology and Civil Engineers was founded in 1997 to support interdisciplinary studies. Its conference proceedings, published in Japanese, report on state-of-the-art restoration projects, and its journal Ecology and Civil Engineering (with English abstracts) is an important reference for restoration. The Ecological Society of Japan and the Japanese Society of Civil Engineering are two other important academic societies promoting river restoration.

River restoration projects provide excellent opportunities for environmental education. The Ministry of Education, Culture, Sports, Science and Technology began the Integrated Study Program for grade-school students, with environmental education as a main topic. River managers lecture at high schools, and their students take part in joint restoration activities.

Restoration activities led by NGOs are flourishing in Japan, though Japanese NGOs have less financial and political power than those in Europe and the United States. About 2800 NGOs are dedicated to environmental conservation (Saito and Onishi 2002). Since 1998, a unique annual event is the National River Day Workshop, a contest and festival of river activities held in July. NGOs, schoolchildren, and river managers present their river-related activities in front of judges. This contest is an energetic and informative event demonstrating the progress in river restoration. Stimulated by the success of the event, South Korean NGOs recently started a similar contest. 


\section{Restoration in practice}

River and wetland restoration projects have been carried out for a variety of reasons. The Itachi River restoration project (Yokohama area), starting in 1982, was one of the earliest such projects in Japan (figure 2 ). The Itachi was an urban river with a straight channel, a flat riverbed, and no recreational value. During restoration, the lower channel was excavated, and sediments were placed along both banks to restore a meandering channel with alternating riffles and pools (figure 2). It was an epoch-making project for a highly regulated urban river. In the 1990s, the Nature-oriented River Works initiative boosted river restoration projects. In the beginning, these projects were primarily designed as flood defense measures. In the 2000s, the improvement of ecological integrity has become the key objective, with a clear shift from projects at the habitat scale to integrated projects of entire corridors. Unfortunately, very few projects in the 1990s have been evaluated. Well-designed appraisals, conducted both before and after project completion, have been implemented only for more recent projects.

Below we briefly introduce and discuss the three best-documented case studies of river, lake, and wetland restoration in Japan: the Tama River, the Kushiro Mire, and Lake Kasumigaura. In addition to these, countless other projects are in progress throughout the country. For example, tidal wetland restoration projects are conducted at the mouths of the Ara River (Tokyo) and the Ibi River (near Nagoya; Suzuki et al. 2003). The riparian wetland restoration known as the "Azame-nose" project along the Matsuura River basin (Kyusyu) is another excellent example of a participation project among local citizens, scientists, and river managers.

Tama River. The 136-km-long gravel-bed Tama River (Tokyo region) exemplifies the typical problems of most Japanese rivers: a high degree of urbanization, dam construction and flow regulation, gravel excavation, loss of exposed gravel sediments, and massive invasion by exotic plants (Shimatani 2003). The catchment covers $1249 \mathrm{~km}^{2}$ with a human population of 4.4 million (average density: 3000 people per $\mathrm{km}^{2}$ ). During the past few decades, the river has evolved from a large, braided gravel-bed river to a singlethread, incised channel fringed by densely forested terraces (figure 3). This geomorphic transformation was caused by (a) gravel excavation during the rapid economic growth period in the 1950s and 1960s; (b) a decline in sediment supply from upstream sections; (c) flow control by the Hamura weir, located $0.5 \mathrm{~km}$ upstream; and (d) fine sediment deposition along the incised channel (Lee et al. 1999, Minagawa and Shimatani 1999, Shimatani 2003). As a result, native plants and animals typical of bare sediments (e.g., Aster kantoensis) disappeared almost completely, while nonnative woods (e.g., Robinia pseudoacacia) rapidly expanded (Kuramoto et al. 1992).
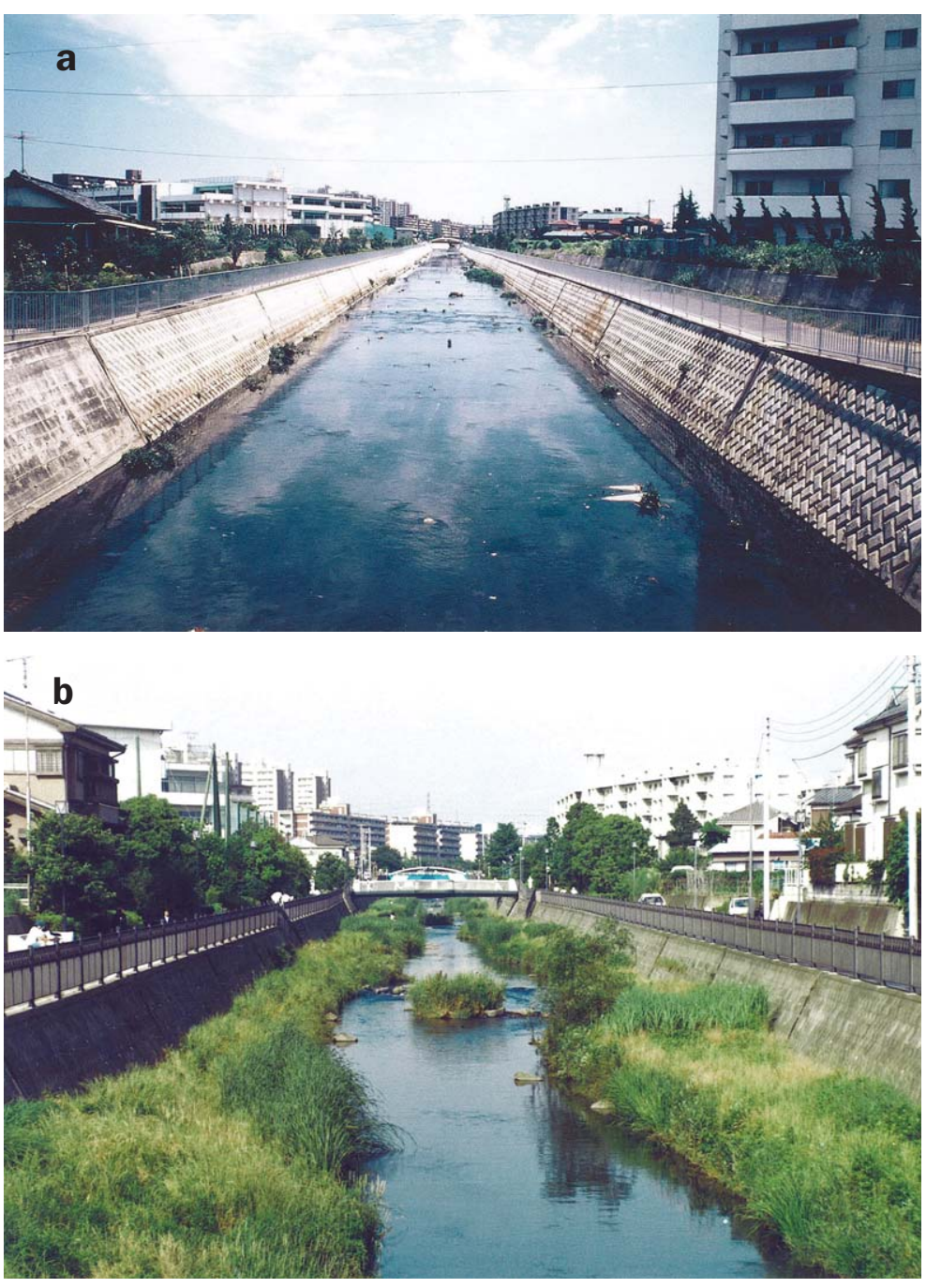

Figure 2. The Itachi River (a) before restoration (1981) and (b) after restoration (1993). Photographs: Shinichi Yoshimura.

The main restoration section (Nagata area) on a large alluvial fan is located halfway along the river corridor $(53 \mathrm{~km}$ from the mouth). It has a slope of $0.46 \%$, a riparian width of $300 \mathrm{~m}$, and a channel width of $30 \mathrm{~m}$. The main goal of the project is to transform the "green" river back to a "white" river. Without active measures, it would take a few hundred years to naturally upgrade the river bed, because of a huge sediment deficiency (Shimatani 2003). Therefore, artificial widening and sediment augmentation are necessary for restoring the gravelbed channel. Restoration has already been conducted at two sites within a $1-\mathrm{km}$ reach. At the upstream site, the conservation of A. kantoensis, an endangered species typical of gravel habitats, was the main goal. Robinia pseudoacacia, an invasive species, and fine sediments were actively removed. At the downstream reach, a 24,000- $\mathrm{m}^{2}$ gravel bed was restored. The inundation frequency of the restored riparian zone now ranges from several times a year to once every 5 years. To increase the sediment supply, gravel was artificially added downstream of the Hamura weir. Although scientific evaluation has not yet been completed, there are obvious signs of 

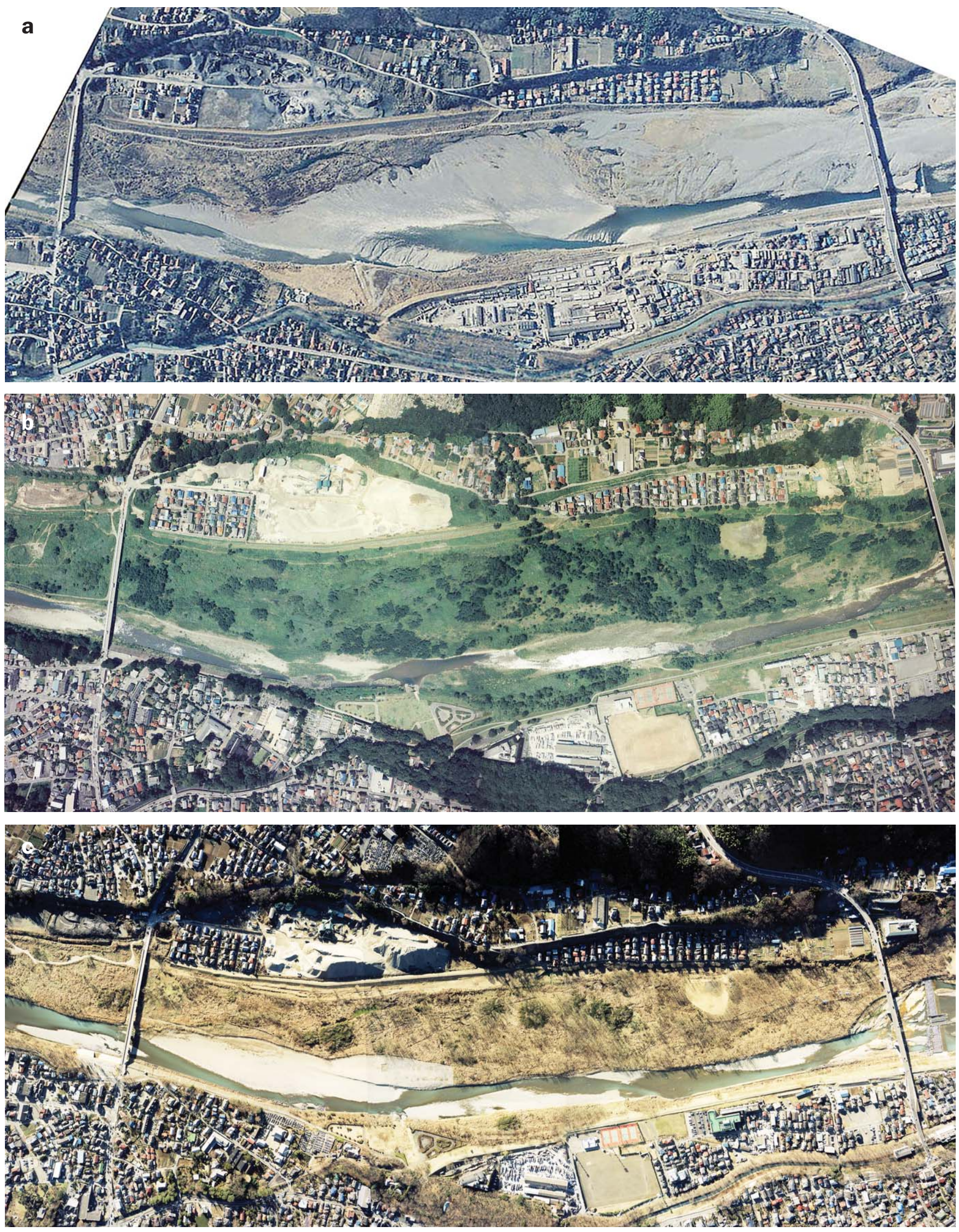

Figure 3. The Tama River (Tokyo) (a) before major river incision (1974), (b) after river incision (1996), and (c) after restoration (2002). Photographs: (a) Geographical Survey Institute, (b, c) Public Works Research Institute. 
recovery. For example, populations of the endangered floodplain grasshopper Eusphingonotus japonicus and of the plant A. kantoensis recovered within a short period (Sin-ichi Suda, University of Tokyo, Japan, personal communication, 22 July 2004).

Kushiro Mire. The Kushiro Mire (Hokkaido) is the largest wetland in Japan (20,000 hectares), which corresponds to about $60 \%$ of the total remaining wetland area of the country (figure 4). Although Kushiro Mire is still one of the country's most pristine landscapes, its area is rapidly shrinking. Moreover, increased sedimentation is transforming the reed-sedge community into an alder (Alnus japonica)-dominated system (Nakamura F et al. 2002, 2004). To develop countermeasures, the Committee for Conservation of the River Environment in Kushiro Mire was established in 1999 (CCREKM 2001). The key target for the next three decades is to maintain the mire in the same state as in the year 2000. To achieve this goal, catchment sediment yield must be reduced by $40 \%$ (from $1400 \mathrm{~m}^{3}$ to $800 \mathrm{~m}^{3}$ annually; CCREKM 2001), and total nitrogen load must be reduced by $30 \%$ (Nakamura F 2003). To put these measures into practice, the Nature Restoration Council for the Kushiro Mire was founded in November 2003 under the Nature Restoration Promotion Law. The council consists of six subcommittees, one on public relations and five on wetland, old-channel, sediment regime, forest, and flow restoration. These subcommittees are responsible for planning, operating, and evaluating all restoration measures, and they report the results to the council. Controlled field experiments and extensive empirical research are carried out concurrently to provide a scientific underpinning for the restoration activities (Nakamura F 2003).
Lake Kasumigaura. The River Law regards lakes as integral parts of the river system; therefore, river authorities also are in charge of lake restoration projects. Eutrophication is still recognized as a serious problem for shallow lakes. At present, however, the ecological degradation of the littoral zonesmainly as a consequence of shore development, water level control, and eutrophication - is the most serious threat to lakes in Japan. Many lakeshore restoration projects have been conducted since 1990, the beginning of the Nature-oriented River Works initiative. The Lake Kasumigaura restoration project is the best documented and largest such project in the country.

Lake Kasumigaura, $60 \mathrm{~km}$ northeast of Tokyo, is the second largest lake in Japan $\left(220 \mathrm{~km}^{2}\right)$. It is a shallow lake (on average $4 \mathrm{~m}$ deep) that drains a densely populated catchment (2157 $\mathrm{km}^{2}$, with a population of about one million people). Eutrophication, bank stabilization, and a controlled water level for flood management and for securing water for households, industry, and agriculture have heavily damaged the littoral vegetation. Between 1970 and 2000, the area of emergent plants decreased by $50 \%$, and submerged plants (former area: 7 million $\mathrm{m}^{2}$ ) disappeared almost completely. Average water transparency decreased from 150 to 30 centimeters $(\mathrm{cm})$. The main turning point was the rapid decline of Nymphoides peltata, or yellow floating heart. In 2001, the Kasumigaura River Office (a branch of the MLIT) initiated large-scale lakeshore restoration measures to conserve $N$. peltata and to restore lake littoral zones. The project involves close cooperation among stakeholders, engineers, and ecologists. The alignment and slope of the banks were designed using old maps and photos and information from reference lakes. Excavated offshore bottom sediments were used for

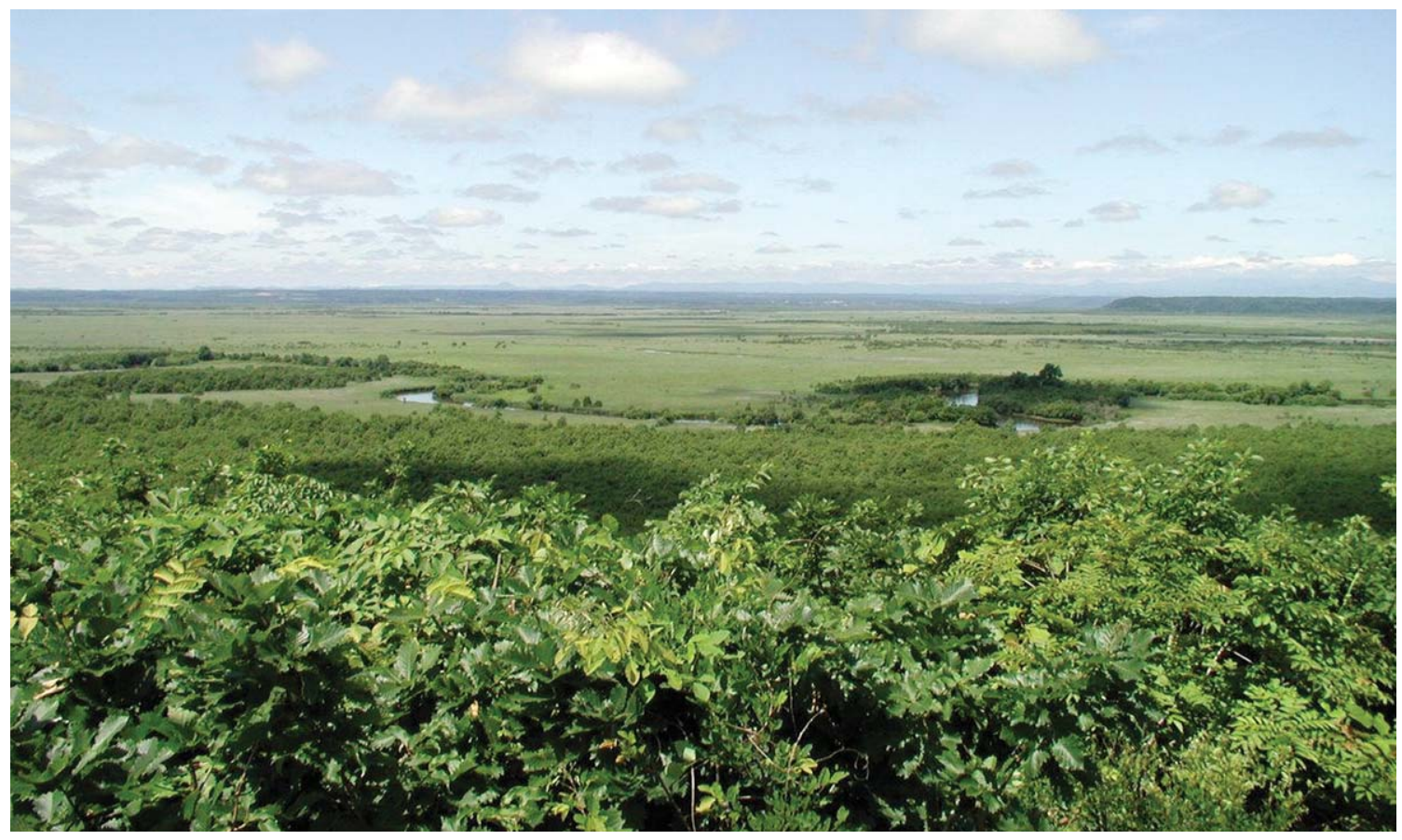

Figure 4. The Kushiro Mire (Hokkaido) is the largest wetland in Japan. Photograph: Keigo Nakamura. 

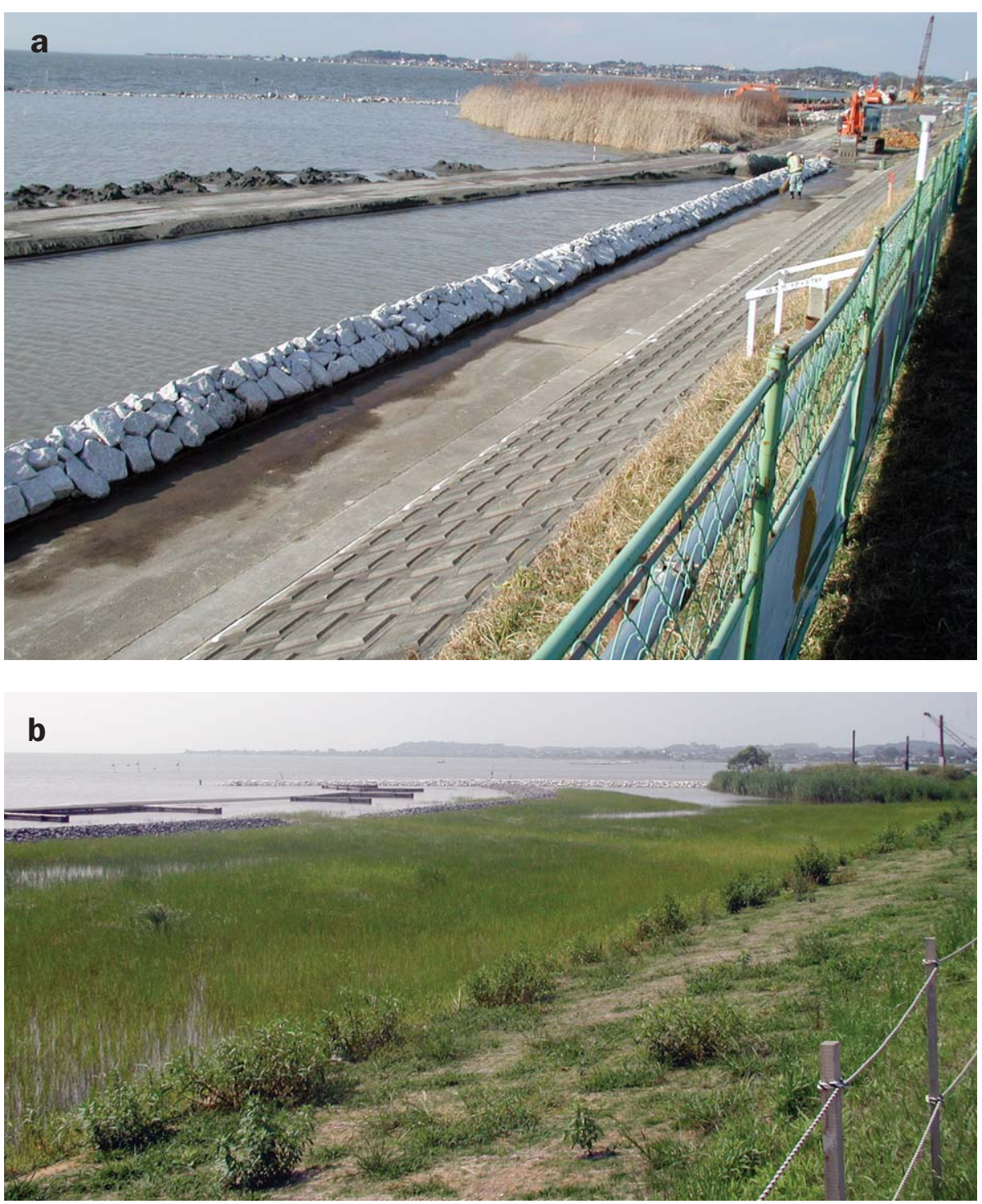

Figure 5. Lake Kasumigaura (a) before and (b) three months after restoration. Photographs: Keigo Nakamura.

restoration. Restored banks were then covered with a $10-\mathrm{cm}$ layer of littoral sediment containing seed banks for vegetation regeneration. Restoration work was completed in spring 2002. The use of natural seed banks led to a rapid recovery of many locally extinct plants (figure 5; Nakamura K 2002, Nishihiro and Washitani 2003). Indeed, some plant species reappeared after 30 years of virtual absence (table 1 ).

\section{Lessons from Japan}

Worldwide, the number of river and wetland restoration projects has increased exponentially during the past few years and is expected to rise further. The main goal of restoration is to link the sustainable use of rivers and wetlands with human well-being. Restoration, therefore, plays an increasing role in environmental management and policy decisions (Bernhardt et al. 2005). If their success remains unproved, however, there is a great risk that public support for restora- tion projects will decline, especially considering the amount of money involved. Therefore, there is an urgent need for scientists and managers to exchange information on restoration practices and evaluation techniques with one another and with the public. Although restoration is flourishing in Japan, virtually nothing is known about these activities outside the country's borders (Nakamura $\mathrm{K}$ et al. 2006). Below we present some lessons that we can draw from the Japanese experience.

Grassroots restoration. In Europe and the United States, many river restoration projects are motivated by powerful international NGOs such as WWF, IUCN, and The Nature Conservancy. In Japan, however, most river restoration projects are driven by local groups and small NGOs (i.e., grassroots initiatives). Although small NGOs have limited financial and technical resources, they can connect local people with scientists and river authorities and therefore trigger large projects. (In the case of Lake Kasumigaura, a local NGO called the Asaza Project initiated the largest lakeshore restoration project in the country; figure 5.) River restoration in Japan began with the activities of a small citizen group. In Ikazaki (Ehime Prefecture), a local NGO was seeking an environmentally sound river management scheme to conserve the Oda River. Members of this NGO visited Germany and Switzerland to learn about ecologically sound management practices ("Naturnaher Wasserbau"). Their zeal led to the launch of the nationwide Nature-oriented River Works program in 1990. Thus, grassroots movements can be key drivers of environmental and social change. Countless NGOs are founded in emerging economies primarily out of fear of irreversible social and environmental impacts of rapid development. Examples from Japan demonstrate that these small NGOs are pivotal in increasing the public demand for sustainable development and nature restoration, and that local NGOs can trigger major restoration activities.

From mountains to the sea: A model for integrated water management. In Japan, rivers link mountains with the sea over quite short distances. Proper headwater management, therefore, is essential for protecting coastal ecosystems. In the Miyagi Prefecture, for example, local fishermen have been 
Table 1. Presence of selected wetland plants at irregular intervals before (1899-1999) and after (2002) restoration of Lake Kasumigaura.

\begin{tabular}{|c|c|c|c|c|c|c|c|c|c|c|}
\hline \multirow[b]{2}{*}{ Species name } & \multicolumn{10}{|c|}{ Year } \\
\hline & 1899 & 1958 & 1971 & 1972 & 1978 & 1996 & 1997 & 1998 & 1999 & 2002 \\
\hline Chara braunii & $\mathrm{X}$ & $\mathrm{X}$ & - & $x$ & - & - & - & - & - & $\mathrm{X}$ \\
\hline Limnophila sessiliflora & $\mathrm{X}$ & $\mathrm{X}$ & $\mathrm{X}$ & - & $\mathrm{X}$ & - & - & - & - & $x$ \\
\hline Vallisneria denseserrulata & - & $\mathrm{X}$ & $x$ & - & $\mathrm{X}$ & - & - & - & - & $\mathrm{X}$ \\
\hline Hydrilla verticillata & $\mathrm{X}$ & $\mathrm{X}$ & $\mathrm{X}$ & $\mathrm{X}$ & $\mathrm{X}$ & - & - & - & - & $\mathrm{X}$ \\
\hline Potamogeton oxyphyllus & $X$ & - & - & - & $\mathrm{X}$ & $X$ & - & - & - & $\mathrm{X}$ \\
\hline Potamogeton perfoliatus & $\mathrm{X}$ & $\mathrm{X}$ & $\mathrm{X}$ & $X$ & $\mathrm{X}$ & - & $X$ & - & - & $X$ \\
\hline Vallisneria asiatica & $X$ & $X$ & $x$ & $\mathrm{X}$ & $x$ & - & $\mathrm{X}$ & - & - & $\mathrm{X}$ \\
\hline Potamogeton malaianus & $X$ & $X$ & $X$ & $X$ & $\mathrm{X}$ & $X$ & $\mathrm{X}$ & $\mathrm{X}$ & - & $X$ \\
\hline Potamogeton crispus & $\mathrm{X}$ & $\mathrm{X}$ & $\mathrm{X}$ & $\mathrm{X}$ & $\mathrm{X}$ & - & $\mathrm{X}$ & $X$ & - & $X$ \\
\hline Ceratophyllum demersum & $\mathrm{X}$ & $X$ & $\mathrm{X}$ & $\mathrm{X}$ & $\mathrm{X}$ & - & - & $\mathrm{X}$ & - & $\mathrm{X}$ \\
\hline Potamogeton pectinatus & $\mathrm{X}$ & $\mathrm{X}$ & $\mathrm{X}$ & $\mathrm{X}$ & $\mathrm{X}$ & - & - & $\mathrm{X}$ & - & $\mathrm{X}$ \\
\hline
\end{tabular}

$\mathrm{X}$, present in ecosystem; -, absent.

Source: Nishihiro and Washitani 2003, Nishihiro et al. 2006.

reforesting headwater catchments since 1989 through an initiative called "The Forest is the Sweetheart of the Sea." Nowadays, countless "fishermen's forest" projects throughout Japan support seashore protection and coastal fisheries (Hatakeyama 1994). Scientists and river managers also study how headwater conditions affect the coastal environment. Furthermore, the continuous migration of people from upstream rural to downstream urban areas has increased public awareness of the complex functional linkages along river corridors. Thus, Japan provides an excellent model for integrated catchment management practices, not only because of its relatively small catchments that respond rapidly to management practices, but also because of the strong social linkages between upstream and downstream human communities. The conservation of headwater catchments is crucial in most developed countries, where land in downstream sections is very limited and, if available, extremely valuable. However, the key challenge is how downstream communities can compensate upstream communities for their conservation activities.

River restoration in a rice-growing culture. Japan's cultural landscape is shaped mainly by rice cultivation. Consequently, water and its environment are very closely linked to human life and culture. Traditional paddy fields provide important habitats for many aquatic species, increase nutrient retention, control floods, and recharge groundwater. Recent agricultural modernization, however, has focused on maximizing crop production (Lane and Fujioka 1998, Brinson and Malvarez 2002). Today there is great demand - not only in Japan but throughout Southeast Asia-for approaches such as reconnecting rice paddies with channels and restoring their hydrological conditions, which allow rice farmers to modernize agriculture without deteriorating the ecological value of this cultural landscape. Therefore, many countries can benefit from Japan's growing experience of managing rice paddies to sustain multiple ecosystem services.

\section{Box 1. Web sites on river restoration In Japan.}

Aqua Restoration Research Center

www.pwri.go.jp/team/kyousei/eng/home-e.htm

ARA [communication site in the Arakawa River basin] www.ara.or.jp/e/e_index.html

Biodiversity Center of Japan www.biodic.go.jp/index_e.html

Ecological Society of Japan/Japanese Journal of Conservation Ecology [with English abstracts] www.esj.ne.jp/esj/index-e.html

Foundation for Riverfront Improvement and Restoration www.rfc.or.jp/english/top.htm

Information Network for River Environment www.rfc.or.jp/rivernetwork/index_en.htm

Infrastructure Development Institute-Japan [English guidelines on river restoration in Japan] www.idi.or.jp/english/00index.htm

Japan Dam Engineering Center www.jdec.or.jp/dc_e/index.htm

Ministry of the Environment www.env.go.jp/en/

River Bureau, Ministry of Land, Infrastructure, and Transport www.mlit.go.jp/river/english/index.html

The Kushiro Initiative: Nature Restoration Project in Kushiro Shitsugen Wetland

www.kushiro.env.gr.jp/saisei/english/top_e.html

River Restoration Research Team, Water Environment Research Group, Public Works Research Institute www.pwri.go.jp/team/kasenseitai/eng/index.htm 
Linking restoration and risk management. A fragile catchment geology, overpopulated floodplains, and a highly dynamic flow and sediment regime make river restoration in Japan a daunting business. Results of recent restoration projects (e.g., the Tama River project) confirm that there is little conflict between the protection of people and property and the improvement of environmental conditions. In addition, various nonstructural measures such as the development of flood hazard maps, local flood fighting corps, and flood warning systems support risk management and reduce excessive river engineering. The new philosophy in river management, namely to reduce flood risks by ecological restoration, has recently been implemented in Switzerland and in many European countries.

Lessons from urban river restoration. Restoration in urban areas involves major risks, challenges, and ecological and socioeconomic constraints. However, urban restoration can also increase the quality of human life (e.g., recreational value) and provide public exposure and appreciation for the value of restoration. Restoring the Genpei River (Shizuoka Prefecture), for example, increased the economic value of adjacent properties. In the Matsuehorikawa River, water quality improvement has restored the local boat cruise and boosted the number of tourists. Today's urban dwellers have begun to demand good environmental conditions rather than convenience. The successful integration of ecological, economic, and social aspects can provide the framework for many urban restoration projects throughout the industrialized world as well as in emerging economies. In South Korea, the recent Cheonggyecheon River restoration project in the center of Seoul was an epoch-making urban river project. The elevated highway in the heart of Seoul was demolished to restore the buried river. The project improved Seoul's landscape, economy, and sightseeing value. In Tokyo, similar projects are under discussion.

Restoration is an iterative and adaptive process, and we hope our article stimulates interest in the multifaceted restoration activities in Japan and facilitates cross-cultural exchange on restoration practices (box 1).

\section{Acknowledgments}

We thank Tomoko Minagawa, Yuichi Kayaba, Keiko Muraoka, Yoichi Kawaguchi, Shingo Yamashita, Jun Nishihiro, Shinichi Yoshimura, Koji Miyatake, Shinichi Suda, and Yukihiro Shimatani for their support in collecting information on river restoration, and Walter Binder, Christian Goeldi, Futoshi Nakamura, Alicia Arrigoni, Sharon Woolsey, Christopher Robinson, Chihiro Yoshimura, Martin Reuss, and Masatoshi Yamawaki for valuable discussions. Three anonymous reviewers provided thoughtful comments on the manuscript. This study was conducted during the special overseas visiting researcher program of the Public Works Research Institute in Japan and was partially supported by a grant to K. N. from the Ministry of Environment in Japan and by a grant to K. T. from the Rhone-Thur Project in Switzerland.

\section{References cited}

Asada H. 1994. Stream Scientist, Bunkichi Okazaki [in Japanese]. Hokkaido (Japan): Hokkaido University Press.

Bernhardt ES, et al. 2005. Synthesizing U.S. river restoration efforts. Science 308: 636-637.

Brinson MM, Malvarez AI. 2002. Temperate freshwater wetlands: Types, status, and threats. Environmental Conservation 29: 115-133.

Brookes A, Shields FD, eds. 1996. River Channel Restoration: Guiding Principles for Sustainable Projects. Chichester (United Kingdom): Wiley.

[CCREKM] Committee for Conservation of the River Environment in Kushiro Mire. 2001. Proposal for the Conservation of the River Environment in Kushiro Mire. Sapporo (Japan): Flood Control Division, Kushiro Development and Construction Department, Hokkaido Regional Development Bureau.

[ESJ] Ecological Society of Japan. 2002. Handbook on Alien Species in Japan [in Japanese]. Tokyo: Chijin Shokan.

[FRICS] Foundation of River and Basin Integrated Communications. 2002. History of flood damage in Japan [in Japanese]. Portal 15: 2-8.

Gippel CJ, Fukutome S. 1998. Rehabilitation of Japan's Waterways. Pages 301-317 in De Waal LC, Large ARG, Wade PM, eds. Rehabilitation of Rivers: Principles and Implementation. Chichester (United Kingdom): Wiley.

Gleick PH, Burns WCG, Chalecki EL, Cohen M, Cushing KK, Mann AS, Reyes RR, Wolff GH, Wong AK. 2002. Number of dams, by country. Pages 296-299 in Gleick PH, ed. The World's Water 2002-2003: The Biennial Report on Freshwater Resources. Washington (DC): Island Press.

[GSI] Geographical Survey Institute. 2001. The change of wetland area in Japan [in Japanese]. (30 March 2006; www1.gsi.go.jp/geowww/marsh/ index.html)

Harada J, Yasuda N. 2004. Conservation and improvements of the environment in dam reservoirs. International Journal of Water Resources Development 20: 77-96.

Hata K. 2002. Perspectives for fish protection in Japanese paddy field irrigation systems. Japan Agricultural Research Quarterly 36: 211-218.

Hatakeyama S. 1994. The Forest Is the Sweetheart of the Sea [in Japanese]. Tokyo: Hokuto.

Ikeuchi K, Kanao K. 2003. The approach and the issue to conservation and restoration for river environment in Japan [in Japanese with English abstract]. Ecology and Civil Engineering 5: 205-216.

Ito S, Osumi K, Kaneko Y, Sakio H, Suzuki W, Nakamura F, Niyama K. 2001. Guidelines of Riparian Forest Management [in Japanese]. Tokyo: Japan Forestry Investigation Committee.

Iyama S. 1993. Profile of Japanese rivers-background to river engineering in Japan. Journal of Hydroscience and Hydraulic Engineering special issue 4: $1-4$.

[JDF] Japan Dam Foundation. 2005. Dam Enchiridion 2005 [in Japanese]. (30 March 2006; wwwsoc.nii.ac.jp/jdf/Dambinran/binran/TopIndex.html)

Kayaba Y. 2003. Activities in the Aqua Research Restoration Center for the restoration of habitats in streams and rivers in Japan [in Japanese with English abstract]. Ecology and Civil Engineering 5: 257-263.

Kondolf GM. 1995. Five elements for effective evaluation of stream restoration. Restoration Ecology 3: 133-136.

Kornhauser DH. 1982. Japan: Geographical Background to UrbanIndustrial Development. New York: Longman.

Kuramoto N, Takenaka N, Washitani I, Inoue K. 1992. A conservation biology of Aster kantoensis growing along the Tama River [in Japanese with English abstract]. Journal of the Japanese Institute of Landscape Architecture 55: 199-204.

Lane SJ, Fujioka M. 1998. The impact of changes in irrigation practices on the distribution of foraging egrets and herons (Ardeidae) in the rice fields of central Japan. Biological Conservation 83: 221-230.

Lee S, Fujita K, Yamamoto K. 1999. A scenario of area expansion of stable vegetation in a gravel-bed river based on the upper Tama River case [in Japanese with English abstract]. Annual Journal of Hydraulic Engineering 43: 977-982. 
Malakoff D. 2004. Profile: Dave Rosgen: The river doctor. Science 305: 937-939.

Malmqvist B, Rundle S. 2002. Threats to the running water ecosystems of the world. Environmental Conservation 29: 134-153.

Matsugane N. 2006. Kabukuri-numa with its unique management method is registered as a new Ramsar site. Paper presented at the International Symposium on Wetland Restoration 2006; 27-29 January 2006, Otsu, Japan. (30 March 2006; www.pref.shiga.jp/kakuka/d/biwako/ symposium2006/program-e/file/k3-e.pdf)

[MEA] Millenium Ecosystem Assessment. 2005. (18 March 2006; www. millenniumassessment.org)

Minagawa T, Shimatani Y. 1999. Study of indices for river restoration on braided river application to Nagata area on the Tama River [in Japanese with English abstract]. Environmental Systems Research 27: 237-246.

[MLIT] Ministry of Land, Infrastructure and Transport. 2001. Countermeasures against Nonnative Species in Rivers [in Japanese]. Tokyo: Foundation for Riverfront Improvement and Restoration.

— 2005. Statistical Data [in Japanese]. (18 March 2006; www.mlit.go. jp/river/jiten/toukei/index.html)

[MLIT and MAFF] Ministry of Land, Infrastructure and Transport and Ministry of Agriculture, Forestry and Fisheries. 2004. The Guideline of a Cooperative Project for Fish Habitat in Local Streams [in Japanese]. (30 March 2006; www.mlit.go.jp/river/kankyou/jigyourenkei.pdf)

[MOC] Ministry of Construction. 1995. Rivers in Japan [in Japanese]. Tokyo: Construction Publication Council.

_ 1997a. Proposed Guidelines on the Clearing and Planting of Trees in Rivers. Tokyo: Sankaido.

- 1997b. Manual of National Census of the River Environment (biological survey) [in Japanese]. Tokyo: Foundation for Riverfront Improvement and Restoration.

[MOE] Ministry of the Environment. 2003. Threatened Wildlife of Japan: Red Data Book, 2nd ed. [in Japanese]. Tokyo: Japan Wildlife Research Center.

Nakamura F. 2003. Restoration strategies for rivers, floodplains and wetlands in Kushiro Mire and Shibetsu River, northern Japan [in Japanese with English abstract]. Ecology and Civil Engineering 5: 217-232.

Nakamura F, Jitsu M, Kameyama S, Mizugaki S. 2002. Changes in riparian forests in the Kushiro Mire, Japan, associated with stream channelization. River Research and Applications 18: 65-79.

Nakamura F, Kameyama S, Mizugaki S. 2004. Rapid shrinkage of Kushiro Mire, the largest mire in Japan, due to increased sedimentation associated with land-use development in the catchment. Catena 55: 213-229.

Nakamura K. 2002. Viewpoints for restoring the lake littoral zone [in Japanese]. Kasen 668: 42-46.

Nakamura K, Amano K, Tockner K. 2006. River restoration: European perspectives and lessons for Japan [in Japanese with English abstract]. Ecology and Civil Engineering 8: 201-214.

Nienhuis PH, Leuven RSEW. 2001. River restoration and flood protection: Controversy or synergism? Hydrobiologia 444: 85-99.

Nishihiro J, Washitani I. 2003. Science supporting nature restoration [in Japanese]. Pages 166-186 in Washitani I, Kusakari H, eds. Nature Restoration Project [in Japanese]. Tokyo: Tsukiji Shokan.
Nishihiro J, Nishihiro MA, Washitani I. 2006. Assessing the potential for recovery of lakeshore vegetation: Species richness of sediment propagule banks. Ecological Research. Forthcoming.

Oguchi T, Saito K, Kadomura H, Grossman M. 2001. Fluvial geomorphology and paleohydrology in Japan. Geomorphology 39: 3-19.

Okayama K. 2001. Conservation and restoration of river environment. Paper presented at the Seventh Japan-France Seminar on Water Management for Rivers, Lakes and Marshes; 1-8 October 2001, Tokyo, Japan.

Osugi T, Yasuda N, Okano M. 2004. Conservation and improvement of the environment around dam reservoirs. Paper presented at the International Commission on Large Dams, 72nd Annual Meeting; 16-22 May 2004, Seoul, South Korea.

Palmer MA, et al. 2005. Standards for ecologically successful river restoration. Journal of Applied Ecology 42: 208-217.

River Bureau. 2004. Summary of the River Bureau budget for the fiscal year 2003 [in Japanese]. Kasen 693: 3-53.

Saito S, Onishi T. 2002. The potential for NGOs [in Japanese]. Nikkei Ecology (August): 25-33.

Sato H. 2001. The current state of paddy agriculture in Japan. Irrigation and Drainage 50: 91-99.

[SBJ] Statistics Bureau of Japan. 2001. Population, Population Change (1995-2000): Area and Population Density [in Japanese]. (18 March 2006; www.stat.go.jp/data/kokusei/)

Shields FD, Cooper CM, Knight SS, Moore MT. 2003. Stream corridor restoration research: A long and winding road. Ecological Engineering 20: 441-454.

Shimatani Y. 2000. Conservation and Restoration of River Environment [in Japanese]. Tokyo: Kajima.

- 2003. Restoration of river channel morphology at the Nagata Area in the Tama River [in Japanese with English abstract]. Ecology and Civil Engineering 5: 233-240.

Suzuki N, et al. 2003. Evaluation of rehabilitation of tidal flat system at the Ibi River mouth [in Japanese with English abstract]. Ecology and Civil Engineering 5: 241-255.

Takeuchi K. 2002. Flood management in Japan-from rivers to basins. Water International 27: 20-26.

Taniguchi Y, Inoue M, Kawaguchi Y. 2001. Stream fish habitat science and management in Japan: A review. Aquatic Ecosystem Health and Management 4: 357-365.

Tockner K, Stanford JA. 2002. Riverine flood plains: Present state and future trends. Environmental Conservation 29: 308-330.

Tsushima K, Ueda S, Ogura N. 2002. Nitrate loss for denitrification during high frequency research in floodplain groundwater of the Tama River. Water, Air, and Soil Pollution 137: 167-178.

Uzuka K, Tomita K. 1993. Flood control planning — case study of the Tone River. Journal of Hydroscience and Hydraulic Engineering special issue 4: 5-22.

Yamawaki M. 2000. Naturnaher Wasser und Strassenbau [in Japanese]. Tokyo: Shinzansya Sci-tech.

Yoshikawa K. 2004. On the progress of river restoration and the future view in Japan and Asia. Pages 43-55 in Geres D, ed. Third European Conference on River Restoration, Zagreb, Croatia, 17-21 May 2004.

Yoshimura C, Omura T, Furumai H, Tockner K. 2005. Present state of rivers and streams in Japan. River Research and Applications 21: 93-112. 